\title{
The Teaching of South African History in the Post-Apartheid Era: Towards Critical and Epistemological Criticisms
}

\author{
Mohlomi Masooa \\ History Learning Facilitator and MA Graduate (History), \\ Free State Department of Education, Bloemfontein, South Africa \\ Email:mmasooa@yahoo.com \\ Chitja Twala \\ Faculty of the Humanities, Department of History, \\ University of the Free State, Bloemfontein, South Africa \\ Email: twalacm@ufs.ac.za
}

\section{Doi:10.5901/mjss.2014.v5n20p2303}

\begin{abstract}
In 2014, South Africa celebrated 20 years of democracy. Within these 20 years of democracy, there were many changes in the education sector. The teaching of history, particularly South African history, has survived many challenges during and after apartheid. During the apartheid era, to a certain extent the teaching of South African history was subjected to political abuse and became a springboard of politicians to justify the existence of the racial divide that had previously engulfed the country. Equally, the study offers critical and epistemological criticisms levelled against the teaching of South African history in secondary schools in the post-apartheid era. The selected criticisms include, inter alia, the question of the relevance of history in post-apartheid South Africa; the limitations of further political abuse of the discipline by educators, as well as the politicians; the lack of analytical skills in the teaching and interpretation of historical facts; and the notion of further perpetuating the racial divide in the country which was once riddled by such divisions. Epistemologically, earlier selected criticisms which took place during the apartheid era will also be referred to, to demonstrate that the teaching of South African history has always been subjected to criticisms that advantaged the then ruling National Party's (NP's) government in South Africa.
\end{abstract}

Keywords: Narratives, Social Sciences, Textbooks, History Instruction, Apolitical, Critical Analysis

\section{Introduction}

The study departs from the premise that contemporary society is dominated by the demand for science and technology, by postulating that the role and place of history should not be understated as it plays an important role in shaping and moulding people and the societies in which they live. In order to understand the complexities of the teaching of South African history in the post-apartheid era, it is important to recognise the reciprocal forces behind it. During this period, education in South Africa was consciously designed on a two-tier system: excellent schools for the whites and less-thanexcellent schools for black South Africans. Separate education departments were also created for the different racial groups. The study provides a unique opportunity as it revisits the criticisms levelled against the teaching of South African history in the post-apartheid era. Critical and epistemological analyses are applied in an attempt to advance what is envisaged by the study; namely, to highlight the criticisms and other relevant dimensional existences of such criticisms. As previously mentioned, criticisms during the apartheid era are referred to as well, and are subjected to the same microscopic analyses. The researchers in this study further note that some of the criticisms in question are as inconclusive as they had been in the past. Interestingly, there is no consensus on these criticisms by all stakeholders involved in the teaching of South African history.

\section{Aims and Objectives}

The aims of these analyses however, is not to create an intellectual collision of observations and experiences in the teaching of South African history, but to provide arguments for and against such criticisms. However, in this study the researchers note that clashes of opinions and interpretations of the relevance of South African history teaching do exist 
and can advance diversified views and unique criticisms. In the context of the above, it is argued in this study that through the criticisms highlighted, a contribution can be made to the body of historical knowledge particularly in the teaching of History. The criticisms levelled against the teaching of South African history are manifold, but for the purpose of this study only a few will be scrutinised. The objectives of this study are:

- To highlight the status of the teaching of South African history in post-apartheid South Africa;

- To scrutinise the criticisms levelled against the teaching of South African history; and

- To make possible recommendations for improving the quality of the teaching of South African history.

\section{Legislative and Theoretical Frameworks}

Since 1994, the South African education system has restructured itself on the principles of equity, human rights, democracy and sustainable social development. New education policies, legislation and governance structures have been developed and implemented on all levels. Therefore, this study is based on an examination of various pieces of legislation, regulations and statutory frameworks that have provided changes in the South African education sector after the demise of apartheid. These legislations, regulations and statutory frameworks in one way or another have had an impact on the teaching of history in South African secondary schools in the post-apartheid era. The legislations and policies include the implementation of the National Qualification Framework (NQF), the Revised National Curriculum Statement for Grade R to 9, and the National Curriculum Statement (NCS) for Grades 10 to 12. The curriculum statements were based on progressive learner-centred, outcomes-based education with an integrated approach to knowledge (Bester et al., 2009: p2).

\section{Research Methods}

As in other similar studies, an interpretivistic paradigm is used as a theoretical framework. Interpretive research is primarily exploratory and descriptive in purpose and is designed to discover what can be learned about the area of interest (Maree 2007: p52). A qualitative research design was adopted as qualitative research is more descriptive and does not require statistics to reach a hypothetical conclusion. It deals with the experiences of participants on a more personal, subjective level and uses a narrative to explain findings.

\section{A Brief Background to the Teaching of South African History during the Apartheid Era}

After 1948, as a result of the ideology of apartheid, curricula in South African schools became entrenched in prejudice, stigmatisation, and stereotyping. As an ideology of superiority, the purpose of apartheid was to secure power to allow the dominant Afrikaner, white and Western values to prevail. To retain power, the dominant group discriminated against, humiliated, and to a certain extent violently oppressed less powerful groups. The opinions and ideas of these oppressed groups were marginalised by the dominant group to an extent that the former had no voice. Therefore, the issue of history textbooks has been at the centre of the educational reform debate in South Africa. The University of Pretoria historian, Charles van Onselen considers the textbook debate "a playground for ideologues and politicians" (Polakow-Suransky 2002: p3). The researchers in this study tend to agree with Apple and Christian-Smith (1991: p4) where they state: "Textbooks embody the selective tradition - it is always someone's selection, someone's vision of legitimate knowledge and culture, one that in the process of enfranchising one group's cultural capital disenfranchises another's".

Under apartheid, history was offered in a way that justified Afrikaner domination and Afrikaner struggles for selfdetermination. Their heroic struggle for survival formed the core of the South African history curriculum. In the past, the threat to Afrikanerdom lay in everything that was non-Afrikaans. The chief threats included: the English, urbanisation, foreign and other African states, the future, communism, and in particular, the large black South Africa population. Chernis (1990: p338) criticises some of the history textbooks which were deemed to be the legitimisation of the Afrikaner political system and nationalist mythology.

\section{The Teaching of South African History in the Post-Apartheid Era}

Like many other countries with a colonial or other legacy in the developing world, South Africa emerged from the apartheid era with massive inherited problems in as far the teaching of South African history was concerned. These problems continued to exacerbate the country's standard of teaching history. Twenty years into democracy, the teaching of South African history is still questionable from other sectors of society. Such a situation adversely affects the state of 
education under the African National Congress (ANC) rule in South Africa. Ironically, the situation partly emanates from the inheritance by the ANC's government of a state which was in socio-political turmoil.

Carl (2009: IV) contends that there is no doubt that since 1994 the South African curriculum scene has been the arena of some of the most expensive changes in many decades. There has been an explosion of knowledge and technological development and demands are being made to include most of these changes in the school curriculum. Therefore, the question remains: To what extent is South African History still relevant in post-apartheid South Africa and what are the criticisms thereof?

In the post-apartheid era, there have been numerous attempts to revive the status of History in South African schools. One such attempt was the establishment of the South African History Project (SAHP 2001-2004) initiated and established by Professor Kader Asmal, the former Minister of Education in South Africa. This initiative followed after the publication of the Manifesto on Values, Education and Democracy and the Report of the History and Archaeology Panel in South Africa in 2001. This report was written by leading scholars who advised the then Minister of Education on the strengthening of the teaching of history in South African schools after the end of apartheid. The South African History Project addressed the challenges of revitalising the teaching and learning of history by setting up provincial networks which brought stakeholders in education, heritage, tourism and publishing together for the first time in post-apartheid South Africa.

During the discussion on the nature of the new South African history in post-apartheid South Africa, the first challenge was to clarify what type of school history would surface. There were two opinions in particular: Should apartheid history be countered with African nationalist views and narratives (an approach called history from below or people's history)? Or should a synthesised account of the past be objective? The new curriculum, known as Curriculum 2005, placed history in the broader category of the social sciences of geography and historical facts. As a result, a content-driven approach was downplayed significantly, thus diluting the subject and a critical analysis of the multilayered South Africa narratives had to be ignored. Interestingly, the new government and specifically former Minister of Education, Professor Sibusiso Bhengu were criticised in the first years of democracy for the continued use of discredited history textbooks from the apartheid era, especially in the most impoverished classrooms in South Africa (Twala, 2005: pp19-39).

\section{Observation and Discussion}

\subsection{Towards a people-centred and relevant history}

History as a school subject has come under heavy scrutiny, considering among other things, its value for learners who choose the subject that is widely considered 'useless'. Even those who chose the subject consider the teaching of History as dull and boring. To develop a sense of a shared future, people need to be exposed to a history that is as inclusive as possible. The study argues that it will not suffice simply to turn the old version of South African history on its head, as that could exclude many people's experiences. In order to achieve inclusivity, it was important to restructure the history taught so that students would be able to find people and incidents in the history lessons with which they could identify. Therefore, to present diverse perspectives of the history of the nation was welcomed.

According to Carl (2009: pp1-3), the school curriculum should address the needs of society by remaining relevant. The school should develop skilled learners that are able to cope in the world of work, but in the process, the role of History as an emotive subject which shapes and moulds learners, should not be negated. SE Tshabalala (2014) recalls: 'In most cases we were forced to teach irrelevant content which had nothing to do with us as black people. In the main, this content glorified the heroes and heroines of the apartheid government. As teachers we were monitored as to what we were teaching and how. This exerted some pressures on us'.

\subsection{Framing a balanced teaching content}

Bam and Visser (2002: p17) aver: "Notice how, in this marvelously jumbled recollection of South African history as taught in schools, the dominant notion is that Europeans play the central role as agents of change and development. Others are included only when whites come into contact with them. They appear as objects for physical description, as parts of the natural landscape, as perpetrators of evil, or as a passive labour force. Overarching all of this is the endless brainnumbering, repetition of what have become historical cliches'. Overall, post-apartheid South African history has chosen to adopt a substantive conception of equality but is still searching for the exact balance in achieving this, without alienating the population groups that were (more or less) privileged under apartheid. 
The sense of history as 'an unavoidable ordeal' has been something experienced by far too many students, whatever their race or background. Bam and Visser (in quoting ZK Matthews, 2002: p21) speak about the narrow and misleading perspective from which school history was taught: "Everything we learned was European in content and viewpoint. We studied South African history, for example, just as it was taught in the European schools, using the same texts and getting the same versions of the facts, and interpretations provided by European historians. However, it required no suggestions from our teachers for us to notice that whenever any black killed any Europeans it was a massacre while the? killing of blacks by Europeans was justified killing".

It is clear from the above that the history content had to be balanced. The ANC as the ruling party had to come up with some amendments to the content of history that was to be taught. Leading history educators and policymakers believed that history education had a central role to play in promoting reconciliation, justice and national unity. These reforms reflected that this could be carried out through a national history curriculum that promoted a new collective history, diverse narratives, and rigour in the application of historical inquiry and interpretation (Tibbitts, 2006: p2).

In June 2014, the South African Democratic Teachers' Union (SADTU) proposed that it wanted history textbooks to be re-written to tell 'the real' South African story. The union believes history should be a compulsory subject at high schools, with particular emphasis on South Africa. SADTU's Deputy Secretary General Nkosana Dolopi was adamant the youth 'have to understand the past to build a stronger future. We want a clear story about the late former president Nelson Mandela. Our children must know that Mandela belongs to the ANC. He was groomed; he was developed by the ANC (Louw and Davids, 2014: p1).

The danger of this statement by Dolopi was problematic as this could lead to the writing of history from the side of the victors. Tshepo Moloi argues the following on the above: 'It shouldn't be that the ANC is portrayed to have been the only liberation party in the struggle or about putting blame on anybody. It should be balanced' (Louw and Davids, 2014: p1).

\subsection{Politicisation of the content}

It is argued in this study that the teaching of history has always been identified as a sphere which has to be used to imprint political ideas and a political outlook to those studying history. In most cases, this approach was defended as a necessary activity towards nation building and the development of national identity as conceptualised by the ruling party or those in political power. The determination to implant political ideas through the politicisation of history as a discipline at different educational institutions was also fuelled by the realisation that these ideas might be conceptualised over a long period of time and enhanced for future political gain.

In a country such as South Africa, the question of knowledge production is crucial to the challenge of national identity and the peaceful existence among peoples who never imagined themselves as belonging to a single national identity. Ndlovu (2013: p2) asserts that post-apartheid South Africa, like many other postcolonial African states that emerged out of the divisive colonial experience, is in the process of crafting solid and cohesive nation building. The question that is repeatedly asked is whether forms of knowledge that previously served to divide the peoples of South Africa have been transformed to support the spirit of unity and a common belonging among South Africans.

The researchers in this study tend to agree with Ndlovu (2009: p69) that the history curriculum, in general, is intended to promote the acquisition of knowledge and the understanding of human activity in the past and to link it with the present so as to help learners understand causes and consequences, continuity and change, and the general evolution of society over time, becoming what it is today. Therefore, history as the study of human activities cuts across the social, economic and political aspects of society. This is in line with the above argument that the history syllabus is closely followed and monitored by politicians and policy makers to ensure that the history that is taught follows the ideology of the ruling elite. Without doubt, it is a well known fact that the practice of history by the community in many parts of the world has been, and still is, aligned with particular political ideologies and political exigencies. Different political regimes emphasise the teaching of a particular aspect of history for particular ideological purposes. Consequently, in most cases, history teaching is manipulated either in positive or negative ways.

In most cases, history has been politicised and used by politicians for identity construction. Scholars such as Friedman (1992a: p207) argue that history is used for identity construction "because the politics of identity consists in anchoring the present in a viable past" and "the past is, thus, constructed according to the conditions and desires of those who produce historical textbooks in the present". The argument that South African History teaching was no longer relevant was based on the premise that the content that forms part of the teaching was essentially politicised. Politicisation of the content was a base upon which the relevance question was raised.

Mouton, Louw and Strydom (2012: p1211) argue that after democratisation in South Africa and consistent with 
South Africa's new constitution, the ANC government abolished the existing racially defined departments of education and established a single education system. This was undoubtedly a laudable enterprise, but it remains an inescapable truth that education is a highly specialised field which can never be successfully served by political appointees. Therefore, it became clear that many of those who were rewarded for their role in the struggle through being given senior appointments were not fit to fill highly specialised posts in the field of education. Thus, following the onset of democratic rule in South Africa in April 1994, it became clear that the transition was a political one and one which was particularly illsuited to the field of education.

\subsection{History and myth-making}

In South Africa during the apartheid era, the teaching of history offered an ideal opportunity for the National Party (NP) government to reach the learners and deliver to them an educational package equal to their perceived worth and status in society. The content of the subject differed according to the different racial groups in the country. In most cases, the content of the subject was tailor-made to endorse the perpetual myth of white superiority and black inferiority in South Africa. Twala (2005: pp27-28) writes: "Another barrier to the new history is the existence of a body of historical myth which has too often been reinforced by the textbooks, as well as by popular books, novels, films, and television series. Over the past years, a considerable amount of research has systematically disproved many of the myths which are still included in textbooks and are still being taught in history classes today... The majority of the textbooks used in the teaching of history had racial connotations which impacted negatively on history as a discipline. In some of these established textbook authors. A typical example of such textbooks is the one written by AN Boyce, drawing on popular accounts dressed up as historical source to flesh out Shaka, the king of the Zulu nation as barbaric. Another typical example is that many history textbooks are shortsighted in interpreting both side of the story of the 1879 battle at Isandlwana between the Zulus and the British. The victory of the Zulus in this regard was interpreted and described as a massacre".

In post-apartheid South Africa, the issue that emerged out of the understanding and teaching of history was the question of how myth-making in the present has been imprinted onto the past.

\subsection{Contextual and methodological issues}

Carr (1961: p9) opines that: "The writing of even contemporary history, consciously or unconsciously reflects our own position in time, and forms part of our answer to the broader question of what view we take of the society in which we live". Moreeng and Du Toit (2013: p45) argue that in recent years, the school subject of history has been subjected to continuous scrutiny aimed at establishing itself as a dynamic subject with regard to knowledge construction and skills development. After 1994, South Africa adopted a new approach to the teaching and learning of history; one that emphasises a learner-centred curriculum linked to the expectations of higher cognitive skills development. This 'ongoing' history approach encourages learners to actively engage in enquiry-based approaches to learning and problem-solving activities, thus effecting interaction with various primary sources in constructing knowledge that can be communicated to the educator and other learners. The main challenge experienced in this regard was that the training that educators received in this regard was below par. To enhance the above, in 2011 Curriculum and Assessment Policy Statement (CAPS) encourages an active and critical approach to learning. This principle requires history educators to structure learning environments that will enable active learner participation and meaningful learning.

\subsection{The diverse nature of South African schools}

In the late 1990s, South African schools underwent enormous changes since the school populations were becoming increasingly diverse, mainly because of the desegregation of the broader society. This increasing diversity resulted in the need for schools to evolve with the changing circumstances, while at the same time maintaining high educational standards (Viljoen, 1998: p8). Recently two educators in the Bloemfontein schools were suspended by the Department of Basic Education for teaching a 'divisive history' whereby black learners were likened to monkeys in a history lesson. The matter was also handed over to the Human Rights Commission for further investigation.

\subsection{The role of history teachers/educators}

Previously in South Africa, the politically conscious across all spheres of government were expected to align with the expectations of the apartheid government. This was to be in line with the expected outcomes for education. For example, 
black educators became the conveyor belt of the content which aimed at relegating their role as those of propagandists. In most cases, these educators were aware of the distortions in the content as taught in most South African schools. The narratives about the successes of the black heroes and heroines were reserved for those instances that depicted their perceived savagery and tendency to self-destruct, while justifications were sought and propagated about the evil deeds of their white counterparts.

With the advent of democracy in South Africa after April 1994 and with the changes effected in the education system, the ideas of the racial superiority of whites in South Africa were conveyed with relative success through the teaching of history. Therefore, the teaching of history as a subject was amongst the first to experience reconfiguration of the content. The challenge was whether to embark on revisionism or to just broaden the horizons of the representation of histories of various racial groups in South Africa in a justifiable and fair manner. However, the wrongs and ills of the past could not disappear on their own. Since the above were enforced through legislation, they had to be undone through corrective legislation as such.

Expected to deal with the distorted history as promoted by the apartheid government, under the new ANC government, the educators of history were faced with the following new challenges: the discontinuation of the subject particularly in the former white schools; the relegation of the subject to the periphery and its being accused of being irrelevant for the job market; a lack of production of history educators as the subject experienced a huge decline in learner numbers in most schools; some Afrikaans-speaking educators experienced challenges in handling contemporary history which included content about the struggle for liberation by the oppressed majority of the African population in South Africa; the question of the 'romantisisation' of history which adopted the 'victors approach'; and the personnel teaching history becoming relatively old and male dominated.

\section{Conclusion}

Although caution needs to be taken in drawing generalised conclusions in a small case study of this nature, the authors are of the opinion that this research has allowed them to say something about the criticisms levelled against the teaching of history in post-apartheid South Africa. The researchers have demonstrated that the teaching of South African history posed challenges in the apartheid era, as well as in the democratisation period during the rule of the ANC in South Africa.

\section{References}

Apple MW and Christian-Smith LK (eds.). The Politics of the Textbook. New York: Routledge Roland.

Bam J and Visser P 2002. A New History for a New South Africa. Cape Town: Kagiso Publishers.

Bester S, Els CJ and Blignaut S 2009. Framework for the development and evaluation of educational DVDs and Web-Based Multi-Media clips for Grade 8 and 9 History, Yesterday and Today, 4: October: 2.

Carl AE 2009. The value of History within the context of science and a technological age, Paper presented at the annual conference of the South African Society for History Teaching, 22-23 September: Sandton: South Africa: 1-3.

Carl AE 2009. The value of History as a school subject in an age of science and technology, Yesterday and Today, 4: October: IV.

Carr EH 1961. What is history? London: Penguin Books.

Chernis RE 1990. The past in the service of the present: A study of South African History syllabuses and textbooks 1839-1990, Unpublished PhD Thesis, Pretoria: University of Pretoria: 338.

Friedman J 1992a. Myth, History and Political Identity, Cultural Anthropology, 7(2): 207.

Maree K 2007. First steps in research. 52. Pretoria: Van Schaik.

Moreeng B and Du Toit E 2013. The powerful learning environment and history learners in the Free State Province, Yesterday and Today, 9: July: 45 .

Mouton N, Louw GP and Strydom GL 2012. A Historical Analysis of the post-apartheid dispensation education in South Africa (19942011), International Business and Economics Research Journal, 11(11), November: 1211.

Ndlovu M 2009. History Curriculum, Nation-Building and the promotion of common values in Africa: A comparative analysis of Zimbabwe and South Africa, Yesterday and Today, 4: October: 69.

Ndlovu M 2013. Mobilizing History for nation-building in South Africa: A De-colonial Perspective, Yesterday and Today, 9: July: 2.

Personal Collection: Interview with SE Tshabalala, History Educators, Qwaqwa, 15 June 2014.

Polakow-Suransky SS 2002. Historical Amnesia? The Politics of Textbooks in Post-Apartheid South Africa, Paper presented at the annual meeting of the American Educational Research Association, September: New Orleans: United States of America: 3.

Tibbitts F 2006. Learning from the past: Supporting teaching through the Facing the Past History Project in South Africa, Prospects, XXXVI, 3 September: 2.

Twala C 2005. Race and ethnicity in the teaching of history: Challenges to history educators in the new dispensation, Journal for Contemporary History, 30(2), September: 27-28.

Viljoen CT 1998. Facing the educational challenges in South Africa: An educo-philosophical reflection, Koers, 69(1\&2): 6. 